\title{
Pengaruh Komposisi Campuran Pasir Silika dan Kapur Tohor Pada Bata Ringan Berbahan Limbah Abu Terbang Batubara
}

Ninis Hadi Haryanti ${ }^{*}$ and Henry Wardhana ${ }^{2}$

\begin{abstract}
Ringkasan
Hasil uji berat volume dan kuat tekan bata ringan masih memenuhi syarat SNI 03-3449-1994 dan SNI 03-0349-1989. Bata ringan $F$ terrendah dengan rerata berat $834 \mathrm{~kg} / \mathrm{m}^{3}$. Kuat Tekan tertinggi pada bata ringan $\mathrm{G}$ dengan rerata Kuat Tekan $25,58 \mathrm{~kg} / \mathrm{cm}^{2}$ (2,56 MPa). Komposisi campuran pasir silika dan kapur tohor memberikan pengaruh nyata (signifikan) terhadap berat volume dan kuat tekan bata ringan. Dari pengujian kuat tekan, bata ringan dengan komposisi kapur tohor rendah mempunyai kuat tekan lebih tinggi dari pada komposisi dengan kadar kapur tohor lebih tinggi. Sementara bata ringan dengan variasi komposisi pasir silika tinggi mempunyai kuat tekan lebih tinggi. Semakin besar penggunaan abu terbang batubara dan kapur tohor akan meningkatkan absorpsi dan porositas tetapi akan menurunkan nilai berat volume bata ringan. Semakin besar porositas maka kuat tekan bata ringan akan berkurang. Secara analisis statistik menunjukkan pemilihan komposisi sama saja, tetapi di rekomendasikan untuk memilih komposisi campuran abu terbang batubara sama dengan pasir silika $28,57 \%$ serta semen $42,86 \%$ (bata ringan $\mathrm{G}$ ).
\end{abstract}

Kata Kunci : bata ringan, pasir silika, kapur Abstract

The volume test results and light brick compressive strength still meet the requirements of SNI 03-3449-1994 and SNI 03-0349-1989. The lowest F light brick with a mean weight of $834 \mathrm{~kg} / \mathrm{m}^{3}$. Highest compressive strength on light brick $G$ with average compressive strength $25.58 \mathrm{~kg} / \mathrm{cm}^{2}(2.56 \mathrm{MPa})$. The composition of the mixture of silica sand and calcium oxide has a significant (significant) effect on volume weight and light brick compressive strength. From the testing of compressive strength, light brick with low calcium lime composition has a higher compressive strength than the composition with higher calcium content. While light brick with variations in the composition of high silica sand has a higher compressive strength. The greater use of coal fly ash and calcium lime will increase absorption and porosity but will reduce the value of light brick volume weight. The greater the porosity, the lighter brick compressive strength will be reduced. In statistical analysis, the selection of compositions is the same, but it is recommended to choose the composition of the mixture of coal fly ash together with silica sand $28.57 \%$ and cement $42.86 \%$ (light brick G).

Keywords: light brick; silica sand; calcium

\section{Pendahuluan}

Perkembangan teknologi material sangat mendukung dalam perkembangan teknologi pada bidang konstruksi, diantaranya adalah pengembangan bata ringan. Bata ringan dipilih, karena di samping ringan, juga dinilai lebih kuat, presisi lebih tinggi, dan efisien bila dibanding bata merah maupun batako.

\footnotetext{
${ }^{*}$ Correspondence: ninishadiharyanti@gmail.com

${ }^{1}$ FMIPA, Universitas Lambung Mangkurat, Jl. A. Yani Km 36 Banjarbaru, Banjarmasin, Indonesia

Full list of author information is available at the end of the article

${ }^{\dagger}$ Equal contributor
}

Diproduksinya bata ringan di Indonesia ini terdorong dengan biaya material dan jasa pembangunan yang melonjak cepat beberapa tahun belakangan ini. Bata ringan ini dipilih sebagai material alternatif yang diyakini mampu menjawab semua tantangan dan kebutuhan tersebut.

Pasir kuarsa (silika) dikenal dengan nama pasir putih. Pasir silika mempunyai komposisi gabungan dari $\mathrm{SiO}_{2}, \mathrm{Al}_{2} \mathrm{O}_{3}, \mathrm{CaO}, \mathrm{Fe}_{2} \mathrm{O}_{3}, \mathrm{TiO}_{2}, \mathrm{CaO}, \mathrm{MgO}$, dan $\mathrm{K}_{2} \mathrm{O}$ yang berwarna putih bening atau warna yang lain bergantung pada senyawa pengotornya. (Masmui dan 
Nandang, 2012) (Callister, 2001). [1] [2] Kualitas pasir silika yang terbaik terdapat di daerah Kalimantan Selatan dengan kadar silika $\left(\mathrm{SiO}_{2}\right)$ berkisar antara 98,7 - 99,9\%. Di Alam, pasir silika ditemukan dengan ukuran butir, mulai fraksi yang halus ( $(0,06 \mathrm{~mm})$ apabila terdapat jauh dari batuan induk, sedangkan ukuran kasar $(¿ 2 \mathrm{~mm})$ terletak tidak jauh dari batuan induk. (Masramdhani, 2011). [3]

Pasir silika pada pembuatan semen berfungsi sebagai pelengkap kandungan silika dalam semen yang dihasilkan. Kandungan silika untuk pabrik semen berkisar 21,3\% $\quad \mathrm{SiO}_{2}$. Pemakaian pasir kuarsa di industri ini bervariasi tergantung kandungan silika bahan baku lainnya, biasanya berkisar antara $6-7 \%$. (Susilo, 2011). [4]

Kapur dapat diklasifikasikan dalam beberapa jenis, yaitu kapur tohor $(\mathrm{CaO})$, kapur padam $\mathrm{Ca}(\mathrm{OH})_{2}$, kapur udara, kapur hidrolis. Hasil penelitian Lisantono, A. dan Purnandani, Y (2010) [5] menunjukkan bahwa kuat tekan maksimum sampel yang optimum adalah beton geopolymer dengan variasi kadar abu terbang : kapur 75\%:25\%.

Jumlah limbah abu terbang dari PLTU Asam asam adalah 43.200 ton per tahun. Dari penelitian yang telah dilakukan, di dapatkan hasil kandungan silika relatif tinggi $\left(74,2 \% \mathrm{SiO}_{2}\right)$ sedangkan alumina tidak terlalu tinggi $\left(5,7 \% \mathrm{Al}_{2} \mathrm{O}_{3}\right)$, dan $\mathrm{Fe}_{2} \mathrm{O}_{3}$ sekitar $14,4 \%$, kandungan logam alkali $(2,4 \% \mathrm{CaO}$ dan $2,03 \% \mathrm{MgO})$, kandungan mineral besi (14,4\% $\mathrm{Fe}_{2} \mathrm{O}_{3}$ ). Kandungan $\mathrm{CaO}$ sebesar 2,4\%, sehingga abu ini merupakan abu terbang yang diproduksi dari pembakaran batubara anthracite atau bituminous, mempunyai sifat pozzolanic dan untuk mendapatkan sifat cementitious harus diberi penambahan semen (Haryanti, 2013). [6]

Abu terbang dapat digunakan sebagai filler karena ukuran partikel yang sangat lembut sehingga dapat sebagai pengisi rongga dan sebagai pengikat antar agregat. Abu terbang biasanya banyak dimanfaatkan dalam perusahaan industri karena abu terbang ini mempunyai sifat pozolanik. (Aziz dan Ardha, 2006, 2011). [7] [8]

Beton ringan adalah beton yang memiliki berat jenis (density) lebih ringan daripada beton pada umumnya. Pada umumnya berat beton ringan berkisar antara $600-1600 \mathrm{~kg} / \mathrm{m}^{3}$. Menurut Tjokrodimuljo (2007) [9], beton disebut ringan apabila beratnya kurang dari $1800 \mathrm{~kg} / \mathrm{m}^{3}$.

Genowefa et. al (2011) [10] meneliti tentang karakteristik beton ringan aerasi AAC (Autoclaved Aerated Concrete) di Polandia. Hasil penelitian menunjukkan berat volume $300-750 \mathrm{~kg} / \mathrm{m}^{3}$ dengan kuat tekan 1,5-5 MPa. Haryanti (2014) [11] meneliti Limbah Abu Terbang Batubara PLTU Asam-asam
Sebagai Bahan Campuran Bata Ringan dengan hasil pengujian kuat tekan masih memenuhi syarat SNI 03-0349-1989.

Tujuan yang ingin dicapai dalam penelitian ini ialah mendapatkan pengaruh komposisi campuran pasir silika dan kapur tohor sebagai bahan pembuatan bata ringan berbahan limbah abu terbang batubara ditinjau dari sifat fisik dan mekaniknya.

\section{Metode Eksperimen}

Parameter yang diuji dalam penelitian ini adalah sifat fisik (berat volume) dan sifat mekanik (kuat tekan) bata ringan. Penelitian dilakukan di laboratorium struktur dan bahan Teknik Sipil Fakultas Teknik Universitas Lambung Mangkurat Kalimantan Selatan. Bahan yang dipakai adalah abu terbang dari PLTU Asam Asam, pasir silika, semen, kapur tohor, air, foam, polimer, hardener. Adapun alat-alat yang digunakan antara lain mesin pembuat busa, cetakan beton, UTM (Universal Testing Machine), timbangan, dan ayakan/saringan.

Komposisi bahan campuran dengan mempertimbangkan hasil penelitian sebelumnya, antara lain: abu terbang dalam campuran pembuatan bahan bangunan dipakai sekitar 20\% (Pelaihari, 2007) [12]. Menurut Cruz (2012) [13], beton dengan campuran tambahan kapur dan bata merah sebesar $20 \%$ dapat digunakan karena nilai kuat tekan dari beton tersebut masih berada di atas kuat tekan beton normal.

Bata ringan yang dibuat berbentuk kubus dengan ukuran $15 \mathrm{~cm} \quad \mathrm{x} 15 \mathrm{~cm} \quad \mathrm{x} 15 \mathrm{~cm}$. Mix desain pembuatan dengan berat bata ringan sebesar 900 $\mathrm{kg} / \mathrm{m}^{3}$. Komposisi campuran bata ringan yang dibuat sebanyak 5 komposisi dengan masing-masing komposisi bata ringan sebanyak 5 benda uji. Komposisi bahan campuran dalam pembuatan bata ringan seperti pada Tabel 1.

\begin{tabular}{|c|c|c|c|c|c|}
\hline No & $\begin{array}{l}\text { Bata } \\
\text { Ringan }\end{array}$ & $\begin{array}{l}\text { Abu } \\
\text { Terbang } \\
(\%)\end{array}$ & $\begin{array}{l}\text { Semen } \\
\text { PCC } \\
(\%)\end{array}$ & $\begin{array}{l}\text { Pasir } \\
\text { Silika } \\
(\%)\end{array}$ & $\begin{array}{l}\text { Kapur } \\
\text { Tohor } \\
(\%)\end{array}$ \\
\hline 1. & $\mathrm{C}$ & 37,50 & 50,00 & 12,50 & 0,00 \\
\hline 2. & D & 37,50 & 37,50 & 0,00 & 25,00 \\
\hline 3. & $\mathrm{E}$ & 42,86 & 42,86 & 14,28 & 0,00 \\
\hline 4. & $\mathrm{~F}$ & 28,57 & 42,86 & 0,00 & 28,57 \\
\hline 5. & G & 28,57 & 42,86 & 28,57 & 0,00 \\
\hline
\end{tabular}

Komposisi Campuran bahan di atas merupakan bahan utama. Selain itu semua bata ringan tersebut diberikan bahan tambah yaitu Foam, Hardener, dan Polymer masing-masing sebesar 0,50\%.

Penggunaan pasir silika dari alur Jorong (Asam Asam) serta kapur tohor diharapkan produk bata ringan berwarna putih dengan tetap menggunakan 
bahan lokal berdasarkan pertimbangan ekonomis. Kapur dapat digunakan sebagai bahan ikat pada beton bila dipakai bersama dengan Semen Portland, karena sifatnya menjadi lebih baik dan dapat mengurangi kebutuhan semen juga dapat sebagai bahan pemutih.

\section{Hasil dan Pembahasan}

\section{Sifat Fisik Bata Ringan}

Karakteristik fisik yang diuji dalam penelitian ini adalah berat volume bata ringan. Hasil 5 komposisi campuran Bata Ringan dengan masing-masing 5 benda uji bila dilihat dari berat volume nya seperti pada Tabel 2.

\section{Tabel 2 Berat Volume Bata Ringan}

\begin{tabular}{clclclc}
\hline \multirow{2}{*}{ Bata Ringan } & \multicolumn{6}{c}{ Berat Volume $\left(\mathrm{kg} / \mathrm{m}^{3}\right)$} \\
\cline { 2 - 7 } & 1 & 2 & 3 & 4 & 5 & Rerata \\
\hline C & 1.037 & 1.067 & 1.095 & 1.067 & 1.126 & 1.079 \\
D & 800 & 874 & 830 & 841 & 830 & 835 \\
E & 859 & 859 & 824 & 844 & 847 & 847 \\
F & 785 & 889 & 830 & 859 & 809 & 834 \\
G & 830 & 841 & 859 & 889 & 844 & 853 \\
\hline
\end{tabular}

Dari Tabel 2 , hasil uji berat volume bata ringan masih memenuhi syarat sebagai bata ringan. Menurut Tjokrodimuljo, beton disebut ringan apabila beratnya kurang dari $1800 \mathrm{~kg} / \mathrm{m}^{3}$, menurut SK SNI 03-3449-1994 dengan berat di bawah $1860 \mathrm{~kg} / \mathrm{m}^{3}$. Berat volume tersebut bila dilihat dengan komposisi campuran nya seperti pada gambar ??.

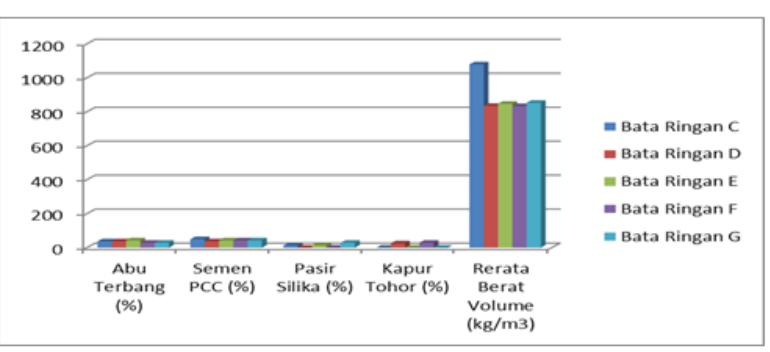

Gambar 1 Rerata berat volume bata ringan dengan komposisi campuran

Dari gambar 1, bata ringan $\mathrm{F}$ adalah bata ringan yang paling ringan dengan rerata berat volume 834 $\mathrm{kg} / \mathrm{m}^{3}$. Komposisi campuran bata ringan $\mathrm{F}$ adalah abu terbang dan kapur tohor $28,57 \%$, semen $42,86 \%$.

Berdasarkan analisis Anova, komposisi campuran pasir silika dan kapur tohor memberikan pengaruh yang nyata atau berarti (signifikan) terhadap berat volume bata ringan. Apabila dilanjutkan dengan analisis Duncan, didapatkan: komposisi campuran bata ringan sampel F, D, E, dan G tidak berbeda secara nyata atau sama, maka pemilihan komposisi tersebut sama saja.

\section{Sifat Mekanik Bata Ringan}

Karakteristik mekanik yang diuji dalam penelitian ini adalah kuat tekan bata ringan. Pengujian kuat tekan bata ringan dengan 5 komposisi campuran dengan masing-masing 5 buah benda uji didapatkan hasil seperti pada Tabel 3 .

Tabel 3 Kuat Tekan Bata Ringan

\begin{tabular}{ccccccc}
\hline \multirow{2}{*}{ Bata Ringan } & \multicolumn{6}{c}{ Kuat Tekan $\left(\mathrm{kg} / \mathrm{m}^{3}\right)$} \\
\cline { 2 - 7 } & 1 & 2 & 3 & 4 & 5 & Rerata \\
\hline C & 26,90 & 24,13 & 21,21 & 28,00 & 22,22 & 24,33 \\
D & 24,15 & 23,49 & 21,72 & 22,22 & 24,00 & 23,12 \\
E & 26,09 & 25,40 & 23,74 & 23,11 & 21,78 & 24,02 \\
F & 27,05 & 23,49 & 25,25 & 24,00 & 22,22 & 24,40 \\
G & 28,99 & 26,67 & 24,24 & 23,11 & 24,89 & 25,58 \\
\hline
\end{tabular}

Hasil rerata kuat tekan bata ringan tersebut masih memenuhi syarat SNI 03-0349-1989, yaitu $21 \mathrm{~kg} / \mathrm{cm} 2$ untuk tingkat mutu IV bata beton pejal. Kuat tekan tersebut bila dilihat dengan komposisi campuran nya seperti pada gambar 2

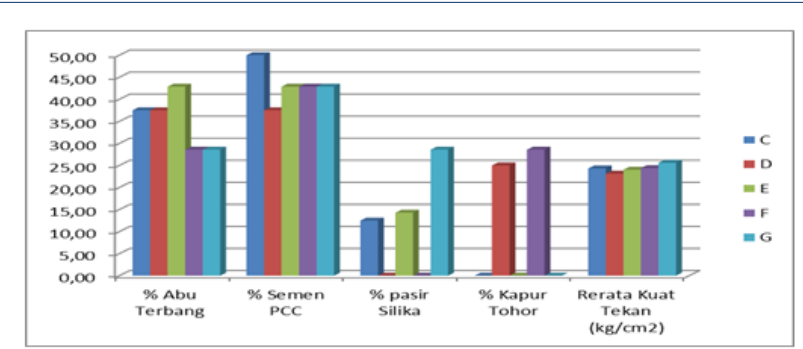

Gambar 2 Rerata kuat tekan bata ringan dengan komposisi campuran

Dari pengujian yang telah dilakukan, seperti terlihat pada gambar 2, rerata Kuat Tekan yang paling besar pada bata ringan $\mathrm{G}$ dengan Kuat Tekan $25,58 \mathrm{~kg} / \mathrm{cm}^{2}$ $(2,56 \mathrm{MPa})$. Komposisi campuran bata ringan $\mathrm{G}$, abu terbang dan pasir silika $28,57 \%$ serta semen $42,86 \%$.

Berdasarkan analisis Anova, komposisi campuran pasir silika dan kapur tohor tersebut memberikan pengaruh yang nyata atau berarti (signifikan) terhadap kuat tekan bata ringan. Apabila dilanjutkan pada analisis Duncan, didapatkan: pemilihan komposisi campuran bata ringan dengan 5 komposisi tersebut sama saja, karena tidak berbeda secara nyata.

Menurut SNI 15-0302-1989, bahan yang mempunyai sifat pozolan adalah bahan yang mengandung sifat silika aluminium dimana bentuknya halus dengan adanya air, maka senyawa-senyawa ini akan bereaksi secara kimia dengan kalsium hidroksida pada suhu kamar membentuk senyawa yang mempunyai sifat seperti semen.

Abu terbang adalah abu sisa pembakaran batubara yang tidak memiliki kemampuan mengikat seperti 
halnya semen. Tetapi dengan kehadiran air dan ukuran partikelnya yang halus, oksida silika yang dikandung oleh abu terbang akan bereaksi secara kimia dengan kalsium hidroksida yang terbentuk dari proses hidrasi semen dan menghasilkan zat yang memiliki kemampuan mengikat.

Kapur adalah suatu bahan material yang dapat digunakan sebagai bahan pengikat dasar sebelum ditemukannya semen. Kapur tohor merupakan jenis kapur yang dihasilkan dari pembakaran batuan kapur. Kapur padam adalah kapur hasil pemadaman dari kapur tohor yang membentuk hidrat (SK SNI S-04-1989-F). Kapur bereaksi dengan bermacam-macam komponen pozzolan yang halus untuk membentuk kalsium silika semen.

Jenis kapur yang baik adalah kapur putih, yaitu yang mengandung kalsium oksida yang tinggi ketika masih berbentuk kapur tohor (belum berhubungan dengan air) dan akan mengandung banyak kalsium hidroksida ketika telah berhubungan dengan air.

Silika adalah mineral utama dari abu terbang batubara jika beraksi dengan kapur maka akan membentuk gel $\left[\mathrm{Ca}(\mathrm{Si})_{3}\right]$. Abu terbang mempunyai sifat pozzolan sehingga bila dicampur dengan kapur dan air akan bereaksi membentuk kalsium silikat hidrat (C-S-H).

Kuat tekan dipengaruhi oleh penambahan kapur tohor dan pasir silika. Dari pengujian kuat tekan, nampak bahwa bata ringan dengan variasi komposisi kadar kapur tohor rendah mempunyai kuat tekan yang lebih tinggi dari pada variasi komposisi dengan kadar kapur tohor yang lebih tinggi. Sementara bata ringan dengan variasi komposisi pasir silika tinggi mempunyai kuat tekan yang lebih tinggi, seperti terlihat pada bata ringan $\mathrm{F}$ dan $\mathrm{G}$ serta bata ringan $\mathrm{D}$ dan $\mathrm{C}$.

Komposisi abu terbang : kapur tohor : pasir silika $=$ $28,57 \%: 28,57 \%: 0,00 \%$ (bata ringan $\mathrm{F}$ ) mempunyai kuat tekan yang lebih rendah dibandingkan bata ringan dengan komposisi abu terbang : kapur tohor : pasir silika $=28,57 \%: 0,00 \%: 28,57 \%$ (bata ringan G). Demikian juga untuk komposisi abu terbang : kapur tohor : pasir silika $=37,50 \%: 25,00 \%: 0,00 \%$ (bata ringan D) mempunyai kuat tekan yang lebih rendah dibandingkan bata ringan dengan komposisi abu terbang : kapur tohor : pasir silika $=37,50 \%$ : $0,00 \%: 12,50 \%$ (bata ringan $\mathrm{C}$ ).

Semakin besar penggunaan kapur tohor menyebabkan campuran bata ringan semakin haus air dan daya lekat semakin kecil. Akibatnya terbentuk bata ringan yang rapuh, mudah mengalami kembang susut dan higroskopis (menyerap air dari udara). Sifat ini menyebabkan bata ringan memiliki massa yang lebih ringan dan memiliki pori lebih banyak.

$\mathrm{xCa}(\mathrm{OH})_{2}+\mathrm{ySiO}_{2}+(\mathrm{n}-\mathrm{l}) \mathrm{H}_{2} \mathrm{O}-i \mathrm{xCaO} \cdot \mathrm{ySiO} \mathrm{SiH}_{2} \cdot \mathrm{nH}_{2} \mathrm{O}$
Persentase kapur tohor yang besar akan menghasilkan bata ringan dengan kuat tekan yang rendah (bata ringan F: $28,57 \%$ dan D: 25,00\%). Kristal $\mathrm{xCaO} \cdot y \mathrm{SiO}_{2} \cdot \mathrm{nH}_{2} \mathrm{O}$ (kalsium silikat hidrat) adalah komponen utama yang memberikan kekuatan pada bata ringan. Reaksi pembentukan kalsium silikat hidrat sangat lambat. Perbandingan $\mathrm{CaO}$ dan $\mathrm{Si}_{2}$ pada kristal juga bermacam-macam dan berpengaruh pada kecepatan pembentukan dan kekuatannya.

Semen merupakan satu diantara bahan perekat yang jika dicampur dengan air mampu mengikat bahan-bahan padat seperti pasir dan batu menjadi suatu kesatuan kompak. Sifat pengikatan semen ditentukan oleh susunan kimia yang dikandungnya. Adapun bahan utama yang dikandung semen adalah kapur $(\mathrm{CaO})$, silika $\left(\mathrm{SiO}_{2}\right)$, alumunia $\left(\mathrm{Al}_{2} \mathrm{O}_{3}\right)$, ferro oksida $\left(\mathrm{Fe}_{2} \mathrm{O}_{3}\right)$, magnesit $(\mathrm{MgO})$, serta oksida lain dalam jumlah kecil. Fungsi semen adalah mengikat butir-butir agregat hingga membentuk suatu massa padat dan mengisi rongga-rongga udara di antara butir-butir agregat. Semakin besar penambahan semen porland maka kekuatan akan semakin meningkat, karena penambahan kompleks $\mathrm{CaO} . \mathrm{ySiO}_{2} \cdot \mathrm{nH}_{2} \mathrm{O}$ yang dikandung oleh bata ringan.

Tetapi disamping semen, kapur tohor pada bata ringan ini memiliki peranan penting sebagai pengikat hidrolis yang akan berikatan dengan $\mathrm{SiO}_{2}$ yang terdapat pada abu terbang batubara membentuk hidrat lain yang dapat meningkatkan mutu bata ringan ini.

Diketahui bahwa abu terbang mampu mengikat sisa kapur yang dihasilkan saat semen bereaksi dengan air. Hal ini disebabkan karena abu terbang bersifat pozzolan. Pada saat proses hidrasi semen akan dilepas kapur bebas, dimana kapur bebas tersebut akan terikat oleh silika dan alumina aktif yang terkandung di dalam abu terbang dan menambah pembentukan silika gel, yang berubah menjadi calsium silica hidrat (CSH) yang akan memasuki pori - pori yang terbentuk, sebagai akibat dibebaskannya $\mathrm{Ca}(\mathrm{OH})_{2}$ pada bata ringan.

Semakin besar penggunaan abu terbang batubara dan kapur tohor akan meningkatkan absorpsi dan porositas tetapi akan menurunkan nilai berat jenis (berat volume) bata ringan. Hal ini terlihat pada bata ringan F. Semakin besar porositas maka kuat tekan bata ringan akan berkurang.

Walaupun secara analisis statistik menunjukkan bahwa pemilihan komposisi tersebut sama saja, tetapi dapat di rekomendasikan untuk memilih komposisi campuran bata ringan G, karena akan menghasilkan bata ringan dengan kuat tekan yang maksimal. Sedangkan untuk mendapatkan bata ringan yang paling ringan berat volumenya, dapat dipilih komposisi campuran bata ringan $\mathrm{F}$. 


\section{Kesimpulan}

Hasil uji berat volume bata ringan masih memenuhi syarat SNI 03-3449-1994 sebagai bata ringan dan bata ringan $\mathrm{F}$ yang paling ringan dengan rerata berat $834 \mathrm{~kg} / \mathrm{m}^{3}$. Hasil uji kuat tekan bata ringan masih memenuhi syarat SNI 03-0349-1989. Kuat tekan yang paling besar pada bata ringan $\mathrm{G}$ dengan rerata kuat tekan $25,58 \mathrm{~kg} / \mathrm{cm}^{2}$ (2,56 MPa). Komposisi campuran pasir silika dan kapur tohor memberikan pengaruh yang nyata atau berarti (signifikan) terhadap berat volume dan kuat tekan bata ringan.

Semakin besar penggunaan abu terbang batubara dan kapur tohor akan meningkatkan absorpsi dan porositas tetapi akan menurunkan nilai berat jenis (berat volume) bata ringan. Hal ini terlihat pada bata ringan F. Semakin besar porositas maka kuat tekan bata ringan akan berkurang.

Dari pengujian kuat tekan, bata ringan dengan variasi komposisi kadar kapur tohor rendah mempunyai kuat tekan yang lebih tinggi dari pada variasi komposisi dengan kadar kapur tohor yang lebih tinggi. Sementara bata ringan dengan variasi komposisi pasir silika tinggi mempunyai kuat tekan yang lebih tinggi, seperti terlihat pada bata ringan $\mathrm{F}$ dan $\mathrm{G}$ serta bata ringan $\mathrm{D}$ dan $\mathrm{C}$.

Walaupun secara analisis statistik menunjukkan bahwa pemilihan komposisi tersebut sama saja, tetapi dapat di rekomendasikan untuk memilih komposisi campuran bata ringan $\mathrm{G}$, dengan komposisi campuran penggunaan prosentase abu terbang batubara sama dengan pasir silika sebesar 28,57\% serta semen sebesar $42,86 \%$.

Author details

${ }^{1}$ FMIPA, Universitas Lambung Mangkurat, Jl. A. Yani Km 36 Banjarbaru, Banjarmasin, Indonesia. ${ }^{2}$ FTeknik, Universitas Lambung Mangkurat, JI.

A. Yani $\mathrm{Km} 36$ Banjarbaru, Banjarmasin, Indonesia.

Pustaka

1. Masmui dan Nandang S., Pembuatan Prototipe Metal Silikon Untuk Bahan Baku Sel Surya,

Prosiding InSINas, 2012.

2. Callister, William D, Fundamental of Material Sience and Engineering / An Interactive. New York; John Willey and Sons, Inc, 2001.

3. Masramdhani Adi, 2011, http://adimasramdhani.wordpress.com/2011/03/13/silikon-dioksida-silicon-dioxide/. Diakses pada tanggal 10 Januari 2013.

4. Susilo, Adi., Presentasi tentang Batuan dan Mineral, Malang: Universitas Brawijaja, 2011

5. Lisantono, A. dan Purnandani, Y, Pengaruh Penambahan Kapur Padam Terhadap Kuat Tekan dan Modulus Elastisitas Beton Geopolimer, Konferensi Nasional Teknik Sipil 4 (KoNTekS 4) Sanur-Bali, 2-3 Juni 2010, Universitas Udayana Universitas Pelita Harapan Jakarta - Universitas Atma Jaya Yogyakarta S - 357, 2010.
6. Haryanti, N.H, Karakterisasi Fly Ash (Abu Terbang) PLTU Asam Asam Kalimantan Selatan Sebagai Bahan Pembuatan Bata Ringan, Jurnal Flux, 2013.

7. Aziz., M; Ardha.,N., Karakterisasi abu terbang PLTU Suralaya dan evaluasinya untuk refraktori cor, Jurnal Teknologi Mineral dan Batubara, no.36, Tahun 14, Puslitbang Teknologi Mineral dan Batubara, ISSN 0854-7890, 2006

8. Aziz., Muchtar, Ngurah Ardha. 2006, Percobaan Pendahuluan Pembuatan Refraktori Cor dari Abu Terbang Suralaya. www.tekmira.esdm.go.id. Di akses pada tanggal 27 Februari 2011.

9. Tjokrodimulyo, K, Teknologi beton, Biro Penerbit KMTS FT UGM. Yogyakarta, 2007.

10. Genowefa Zapotoczna, et. al., Autoclaved Aerated Concrete Properties on the basis of current research results conducted by $\mathrm{ICiMB}$ - Research and Development Center for Cellular Concrete Industry CEBET and Building Research Institute. Handbook for AAC producers and users. Magazine of Concrete Producers Association. 5 Interantional Conference of Autoclaved Aerated Concrete, 2011.

11. Haryanti, N.H, Limbah FlyAsh (Abu Terbang) Batubara PLTU Asam-asam Sebagai Bahan Campuran Bata Ringan, Prosiding Nasional ISSN: 1411- 4771 Simposium Fisika Nasional XXVII (SFN 2014) Universitas Udayana Bali, 2014.

12. Pelaihari, Flay Ash sebagai Substitusi Semen, Puslitbang Teknologi Mineral dalam Batubara, 2007.

13. Cruz, J.d, "Analisis Kuat Tekan Beton K175 dengan Campuran Serbuk Kapur dan Serbuk Batu Bata Untuk Penghematan Penggunaan Semen Sebagai Bahan Pengikat Dasar", Universitas Komputer Indonesia, Bandung, 2012. 